\title{
Role of fluids in Fe-Ti-P mineralization of the Proterozoic Damiao anorthosite complex, China
}

\author{
LI-XING Li AND Hou-MIN LI
}

MNR Key Laboratory of Metallogeny and Mineral Assessment, Institute of Mineral Resources, Chinese Academy of Geological Sciences, Beijing 100037, China (llxing@cags.ac.cn)

The orebodies in the Damiao $\mathrm{Fe}-\mathrm{Ti}-\mathrm{P}$ deposit are commonly characterized by chlorite-dominated alteration on both sides of the orebodies in contact with the host anorthosite, suggesting the presence of hydrothermal fluid during mineralization. Baddeleyite blebs and lamellae in the primary ilmenite of anorthosites and $\mathrm{Fe}-\mathrm{Ti}-\mathrm{P}$ orebodies in the Damiao anorthosite complex formed as a result of decreasing solubility of $\mathrm{Zr}$ in ilmenite during slow cooling and consequent exsolution of $\mathrm{ZrO}_{2}$. Two types of zircon formation are identified and both are related to hydrothermal replacement of baddeleyite by Si-rich fluids. The type-I zircon intergrown with magnetite-rutile symplectite indicates a temperature of $>700{ }^{\circ} \mathrm{C}$ for fluid segregation from the $\mathrm{Fe}-$ Ti-P-rich melt. The type-II zircon occurring as tiny aggregate in the chlorite-quartz-titanite-bearing replacement fronts in the altered anorthosite suggests that the hydrothermal fluid flow was still active at $\sim 350^{\circ} \mathrm{C}$. The $\mathrm{Fe}-\mathrm{Ti}-\mathrm{P}$ mineralization of the Damiao anorthosite complex was associated with magmatic-hydrothermal processes, with the $\mathrm{Fe}-\mathrm{Ti}$ oxides being formed at the magmatic stage and apatite precipitated throughout the magmatic-hydrothermal stages. The concentration of apatite at the top and marginal domains of the $\mathrm{Fe}-\mathrm{Ti}-\mathrm{P}$ orebodies likely resulted from hydrothermal processes, rather than magmatic crystal accumulation. 